\title{
BIOREGIONAL APPROACH TO INTEGRATING TRANSPORT NETWORKS AND NATURAL AREAS IN THE LAZIO REGION COASTAL AREA, ITALY
}

\author{
ALBERTO BUDONI \& VALERIO MAZZESCHI \\ La Sapienza University of Rome, Italy
}

\begin{abstract}
"Bioregion", a term coined by Peter Berg in 1977, was improved by Alberto Magnaghi, who defined it as the space for developing new relationships of coexistence between the inhabitants-producers and the territory of a region. Therefore, bioregion is a tool for rethinking regional planning, no longer as the sum of different sectorial planning exercises, but as a "transdisciplinary planning" approach that considers all of a territory's aspects. This approach is related to EU policies for Integrated Coastal Zone Management (ICZM) and the protection of maritime and coastal areas. This paper presents a case study on the coastal areas of the Lazio region of Italy which have a great many natural areas but which is also one of the most anthropized areas in the region. Indeed, due to the rising population, many interventions in the coastal areas resulted in the transformation of natural zones into urban areas. One effect has been urban sprawl and the related lack of capillarity of the public transport network. The result was that many ecosystems and natural areas were fragmented, losing their biodiversity. With a view to reconnecting these fragmented areas, this paper discusses a new regional scenario based on enhancing the linkages between land transport networks and the maritime gateway. In this scenario, railway corridors would stimulate a new organisation for the region's settlements by representing not only the network connecting the bioregion's cities and towns but also the cornerstones for the environmental regeneration of the coastal areas.
\end{abstract}

Keywords: bioregion, railways, ports, ICZM, transport corridors.

\section{INTRODUCTION}

The globalization of markets marked by increases in goods production and tourist flows has determined and will continue to determine higher volumes of maritime transport. In the European context, the increment is likely to be increasingly strong due to the combination of two factors: (1) the EU's transport policies as laid down in the 2001 white paper [1] where the creation and strengthening of "motorways of the sea" are seen as one of the pillars for transport efficiency and environmental sustainability due to their key role in furthering intermodality and the decongestion of road infrastructures for the movement of goods; and (2) the new silk route called the "Belt and Road Initiative (BRI)" under China's policies for commercial and infrastructural expansion, which has, as one of its fundamental pillars, a focus on maritime transport, the organization of efficient port areas for container traffic, and full integration with road and railway networks. The pressure on coastal areas will therefore increase, due not only to the impact of rising goods and passenger flows, but also to the need to upgrade port infrastructures both at sea and on land, including the roads and railways in the hinterland and hence the settlement system as a whole. These pressures will join the broader and more generalized ones that have characterized the European coasts in recent decades. As noted in 2007 by the European Commission: "Population growth in coastal regions and islands has been double the EU average over the last decade. Coastal communities are also the destination of the majority of tourists in Europe, making the need to reconcile economic development, environmental sustainability and quality of life particularly acute in these regions" [2]. The EU's attention to coastal strips was already evident in 1995 [3], but it was first developed in an expert document on general principles 
and political reflections [4]. Then a Recommendation of the European Parliament and of the Council of 2002 [5] set the guiding concepts "for a strategic approach based on an ecosystem approach of the natural resources of both the marine and terrestrial components of the coastal zone and a broad overall perspective (thematic and geographic) which will take into account the interdependence and disparity of natural systems and human activities with an impact on coastal areas" [5]. Based on these guiding concepts, and interacting with other sectoral norms including the Marine Strategy Framework Directive [6] which reiterates the need for an ecosystem-based approach to the management of human activities and delimits the marine regions or sub regions, the EU developed a directive establishing the framework for maritime spatial planning (MSP) [7].

Member States had to comply with this Directive by 18 September 2016. It states that the maritime spatial plans shall be established as soon as possible and at the latest by 31 March 2021. Through these plans, "Member States shall aim to contribute to the sustainable development of energy sectors at sea, of maritime transport, and of the fisheries and aquaculture sectors, and to the preservation, protection and improvement of the environment, including resilience to climate change impacts. In addition, Member States may pursue other objectives such as the promotion of sustainable tourism and the sustainable extraction of raw materials" [7].

The Directive is a step forward in the planning of maritime space, but not decisive for coastal zone planning. In fact, coastal areas are excluded even though they were part of it at the beginning of the approval process. The Member States insisted on maintaining their competence and full discretion over the management of their coasts and in particular over coastal urban planning [8]. This once again demonstrates the EU's difficulty in developing integrated policies, particularly when dealing with aspects of land-use planning in urban areas. It is therefore not surprising that attention to the environmental aspects of the motorways of the sea in the Detailed Implementation Plan of the European Coordinator [9] is limited to the environment within the ports and to the pollution caused by the ships; the coastal environment in terms of its relationship both with the maritime space and with the hinterland.

\section{THE DIFFICULTIES OF INTEGRATED MANAGEMENT OF THE COASTS AND BIOREGIONAL CONCEPTION}

Integration is not a problem only at the normative level, however; it is also a problem of establishing its meaning. In fact, although integration has long been seen as necessary for maritime and coastal planning in various international conventions (e.g. the United Nations Framework Convention on Climate Change of 1992, and the Convention on Biodiversity, especially the program entitled "Integrated Marine and Coastal Area Management (IMCAM) approaches for implementing the Convention on Biological Diversity" of 2004 [10]), it is not clear how this is to be done nor what it implies in the different contexts of MSP. Saunders et al. [11] examined different dimensions of integration across several MSP case studies and through an analytical framework which includes: cross-border (integration across administrative borders), policy and sector integration (MSP aspirations to achieve balanced outcomes of the environmental, social and economic pillars), stakeholders (how stakeholders are engaged with during different MSP policy phases), knowledge (consideration of platforms and processes that support data and knowledge coordination and sharing among relevant authorities, sectors and levels), temporal integration dimensions (focus on how marine planning seeks to consolidate "the now with the future"). What emerges from this framework regarding different dimensions of integration "is that how they are interrelated in practice is always contingent on the particular empirical setting, i.e. just because a wide range 
of stakeholders participated in MSP does not necessarily mean that stakeholders were influential or that different knowledge types were meaningfully considered in decisionmaking" [11]. This specificity of contexts and processes is not easily standardized by using software-based simulation and analytical tools since, although they are frequently mentioned in the scientific literature on marine management approaches, these are still mainly used in academic circles and have not yet found their way into everyday MSP practice [12]. Improving software-based, analytical tools and scientific knowledge in general is important but it cannot be the only working guideline.

According to the analytical framework developed by Saunders et al., an integrated coastal zone planning and management effort should:

- define planning and management areas that are not determined by administrative boundaries but rather by agreements and contracts with entities and actors (e.g. the coastal contracts in France) [13];

- develop planning strategies that set out a vision for the future development of a place in ways that pursue environmental, social and economic objectives;

- involve stakeholders interactively as from the start of the planning process, during public meetings and using appropriate communications tools;

- insert acquired knowledge into a GIS recognized by the various sectors and levels and ask scholars, associations and inhabitants to help expand the information base in the framework of an effective participatory process (PPGIS);

- promote, wherever possible, studies with a transdisciplinary character designed to overcome the barriers between the various disciplines and strengthen the holistic interpretation of territorial systems;

- consolidate "the now with the future" by designing territorial projects that use innovative technologies in the feasibility studies of the works that compose the vision of the future to be developed.

These ways to tackle integration issues, which the authors believe are widely shared among those involved in spatial, regional and urban planning, are not, however, enough to address what many call a new era of urbanization. A clearly regionalized urban era [14] where the urban and regional realities, previously distinguished from each other, are merging within a dynamic involving a concentration of prestigious functions in urban areas and the expansion of urban sprawl in the plains and on the coasts. It is necessary to combine the interpretative utility of the concept of the urban region with a co-evolutionary vision between culture and nature, with a view to detecting lasting relationships between human settlements and the environment; to this end, it is possible to apply the concept of bioregion. A concept that can, through rediscovery and redefinition, become one of the reference points for rethinking the problems of contemporary territorial transformations. It is noteworthy that the first definition of bioregion formulated by Berg and Darsmann [15] did not focus on ecological determinism, but rather on an integrated vision of natural features and of how communities have historically interpreted their relations with the environment. Indeed, while it is true that physical abiotic and vegetal features prevail in the initial delimitation of a bioregion, the final result is closely linked to the boundaries that the inhabitants, themselves, recognise as their living environment. Even in the most recent formulations of the concept of bioregion, the latter is defined in terms both of its ecological and human systems [16]. In the Italian context, Magnaghi has re-proposed a bioregionalist approach to territorial planning [17] whose characterizing element is the affirmation that, to obtain lasting equilibrium between human settlement and environment or a bioregion capable of supporting itself, it is necessary to 
develop new forms of co-evolutionary relationships between inhabitants/producers and the territory, based on the care of its assets considered as common goods. Further, to improve the capacity of inhabitants to recognize the territorial heritage, both physical and immaterial (social relations), the delimitation of a bioregion can become a fundamental factor of cultural growth and civic awareness, able (for example) to define a reference space for relationships between the maritime space and the coastal strip and between the latter and its hinterland. A relationship in the latter case that is not, as often understood, limited to the narrow strip parallel to the shoreline but that comprises all the systemic components that influence its conformation and the quality of its ecosystems, starting with the hydrographic network.

\section{THE RELATIONSHIP BETWEEN THE MOTORWAYS OF THE SEA AND COASTAL MANAGEMENT TOOLS IN THE ITALIAN CONTEXT}

In post-World War II Italy, the coasts were basically seen as summer leisure venues and the state-owned beaches were occupied by private concerns who altered them radically by building second homes or, in the south, by illegal construction. In a complementary manner to these dynamics, port development was characterized by a proliferation of tourist ports and the growth of commercial harbours for goods and passengers isolated from the hinterland [18]. Overall, although Italy has about $7,500 \mathrm{~km}$ of coastline, legislators have rarely intervened to manage their development of coastal areas or even to safeguard their rich natural heritage [19]. Only in the last decade has the regulatory framework evolved in response to the thrusts of EU regulations, also as a consequence of the economic crisis and the dynamics of globalization. By virtue of its position in the middle of the Mediterranean, Italy could become a partner for China's policies that call for a strong reliance on maritime transport, playing the role of political mediator and infrastructural hub for the other developed Western countries [20]. Normative changes have addressed the infrastructural policies for motorways of the sea and harbours, as well as maritime spatial planning and coastal zone management.

Of particular importance in the first case is Legislative Decree 169/2016 (integrated and modified by Legislative Decree 232/2017) which innovated harbour-planning methods by abandoning the single port regulatory approach (in Italian PRP) to the planning of the national port system as a whole (in Italian PRdSP). The main texts of the new regulatory framework relating to infrastructures, transport and logistics are [21], [22]:

1. The National Strategic Plan for Ports and Logistics, which aims to reorganize the system of harbours and logistics and which has the following pillars [23]:

- interconnectivity, such as quality of last-mile connections;

- intermodality, through the use of different modes of transport for goods;

- integration between different sectors, both administrative and legislative;

2. The 2014 and 2015 National Operational Program for Infrastructures and Networks;

3. The Master Plan for Southern Italy;

4. Connecting Italy: Strategies for transport infrastructures and logistics.

The above set of rules and documents creates a new programmatic framework that, above all through the PRdSPs, should favour abandoning of the planning of individual ports in favour of the planning of integrated systems. The related tools include: links between general urban planning and port planning, distinguishing the port itself and city-port interaction as two sub-areas; the stipulation of "strong" agreements with the municipal administrations; and the identification, on a territorial scale or "vast area" that includes several municipal territories, of the infrastructural corridors that the port system needs in order to connect the port nodes with the major communications networks and with the logistics/transport nodes 
of the overall territory [24]. While this approach seems effective for tackling the functional problems of the relationship between ports and road and railway infrastructures, it is noteworthy that the environmental aspects (as for the Detailed Implementation Plan for Motorways of the Sea [9]), not considered except for the risk of obstruction by sediments (in all these documents the ICZM is never mentioned). This oversight appears all the more striking considering the importance that the integrated management of coastal areas has assumed in the Mediterranean, and hence for Italy, since the Barcelona Convention was signed on 16 February 1976, by 16 governments and ratified by Italy through Law 30/1979 [25]. The Convention, which is a legal and operational instrument of the UN Plan of Action for the Mediterranean (MAP), fostered an increasingly broad concept of protection that is clearly defined in the Protocol on Integrated Coastal Zone Management in the Mediterranean [26]. Also worthy of note is the Legislative Decree 201/2016 which, in implementing the EU Directive 2014/89 [7], created an inter-ministerial coordination table that developed the guidelines for orienting the preparation of management plans for maritime spaces. These plans, which must be drawn up by 31 December 2020, will cover all the anthropic activities affecting the maritime space except those whose sole purpose is national defence or security, and those that affect, entirely or partially, the coastal waters already covered by urban or rural plans. The framework of norms and instruments therefore appears to be broad and well defined, albeit lacking the fundamental element that determines the quality and effectiveness of ICZM. However, if there is a clear will of the actors, the issue could be addressed by implementing coastal contracts as done in France and by learning from the experiences of some Italian areas, and making special effort to integrate the problems of port infrastructures and the movement of goods and passengers. The analysis of specific case studies and the definition of scenarios can therefore play a prominent exploratory role in the advancement of the planning framework.

\section{THE COASTAL/INFRASTRUCTURAL SYSTEM OF LAZIO REGION}

The Lazio coast is about $360 \mathrm{~km}$ long. Its 21 municipalities are divided into two provinces (Latina and Viterbo) and one metropolitan city, namely Rome. The coastline is mostly a straight line with flat, sandy beaches.

The regional territory, like most of the Italian peninsula, is dominated by the longitudinal, North-South development of the Apennine Range, leading the designers of the major rail and road infrastructures to choose routes along the coast [27]: e.g. the railway line linking Rome to Naples via Formia, the Tyrrhenian railway linking Rome to Pisa, and the national highway SS1-Aurelia. The result is a heavy concentration of infrastructures along the coastal strip [26], but management by many different actors cannot assure efficient intermodal mobility for flows of goods and people.

The presence of Italy's capital, Rome, within Lazio region further aggravates the imbalance of the territory's infrastructural situation since almost all the rail and road routes start/end in Rome. Further, the whole of Lazio region has experienced rapid urban expansion, both legal and especially illegal, as reported by Legambiente [28].

Fig. 1 shows the rates at which the populations of all the coastal municipalities of Lazio but one - namely the X municipality (Rome) - grew between 1951 and 2018.

The highest rates were experienced by the municipalities closest to Rome: the populations of Ardea, Ladispoli and Pomezia grew by over $1500 \%$, with Ardea recording the highest rate (2196\%). Trends were fairly flat for the municipalities along the Pontine coast.

The region's three major ports are governed by the Port Authority of the Central and Northern Tyrrhenian Sea: 


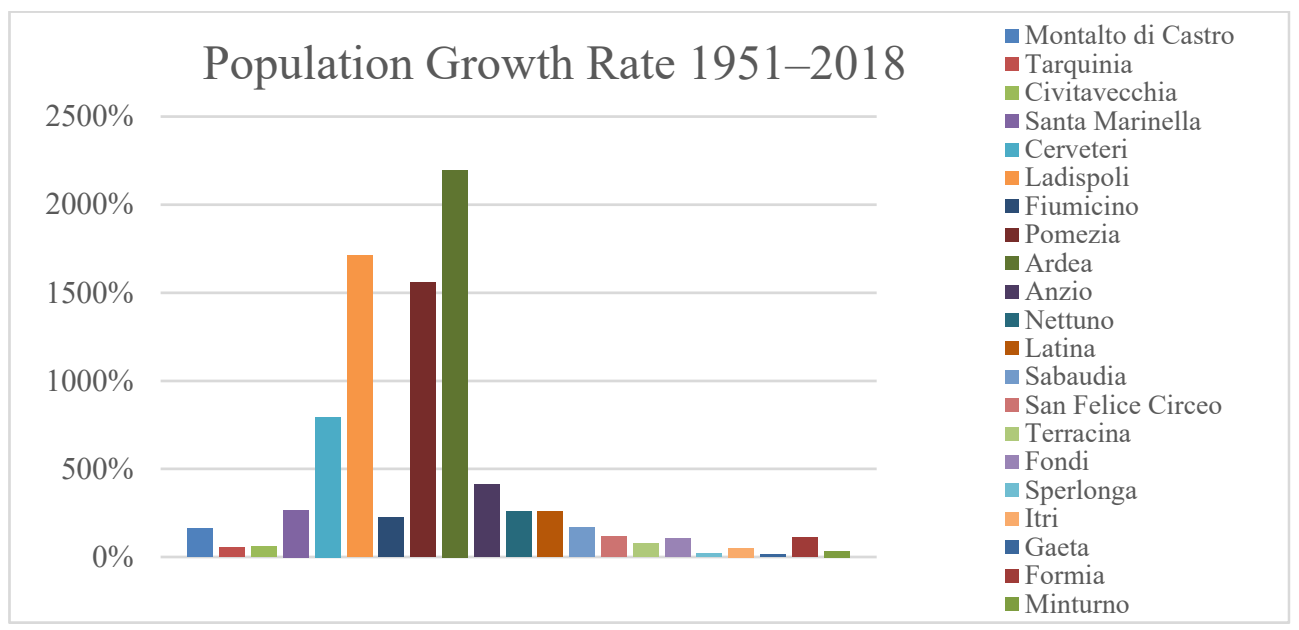

Figure 1: Population growth rate in Lazio region coastal area, 1951-2018.

- the Port of Civitavecchia, which is extremely important as a freight terminal for the whole of central Italy, is the largest passenger terminal in Lazio and one of the hubs of the Motorways of the Sea;

- the port of Fiumicino, which is dedicated mainly to the off-loading of petroleum products, is one of the nodes of the Tyrrhenian corridor thanks to its proximity to infrastructures and sites of great commercial and economic interest like the "Leonardo Da Vinci" international airport, the Rome fairgrounds, and the superhighway linking the Tyrrhenian corridor and Rome's ring road (the Grande Raccordo Anulare, GRA);

- the Port of Gaeta, which is an important stopover only for the territory comprising Sud Pontino, Frusinate and Upper Caserta. Most of the food products produced in these areas are shipped from this terminal.

Landings, in particular, can be viewed as ports-in-waiting until a larger infrastructures can be built that will, in most cases, raise serious environmental concerns or, alternatively, permit expansion of the network of ports in order to redistribute passenger and goods flows more sustainably along the entire Lazio coast.

The infrastructural network is made by: Superhighway (A12 Civitavecchia NordTarquinia), National Highway (SS1 Aurelia, SS7 Appia), Regional road (SR 148 Pontina, SR 206 Nettunense), Provinaicial Road (SP8 via del Mare, SP601 Ostia-Anzio), Multifunctional Port (Civitavecchia), Commercial and Tourism (Gaeta, Terracina, Anzio, Fiumicino, Formia), Tourism (Nettuno, Santa Marinella, Ostia, San Felice Circeo, Sperlonga), Main line Railway (Roma Napoli via Formia, Roma-Pisa), Secondary line Railway (Roma-Nettuno), Node Line Railway (Roma Fiumicino).

This list shows that the road network definitely has the greatest number of connections in the transport system. The region has only one true port hub, namely Civitavecchia, where almost all the logistics resources are concentrated. Although the other ports are important for passenger transport to the Pontine archipelago, their role remains confined to that of purely regional ports. The railway network's two main lines run North-South while scarce, if not entirely absent are the transversal connections. 
East-West links used to be assured by three lines: Civitavecchia-Capranica-Orte, GaetaFormia-Sparanise, and Terracina-Priverno. All three lines are suspended or abandoned (the first two were completely dismantled) [29].

The strong urbanization thrust mentioned earlier has provoked widespread fragmentation of ecosystems and areas of high naturalistic value. In the following lines there is the list of the protected areas of the coastal and marine areas of Lazio region. The protected areas outside the Natura 2000 Network include 19 marine areas that are part of the Sites of Community Interest [30] and they are: National Park (Parco Nazionale del Circeo), Regional Park (Riviera di Ulisse), State Nature Reserves (Foresta demaniale Circeo, Lestra della Coscia, Litorale Romano, Pantani d'Inferno, Piscina della Gattuccia, Piscina della Bagnatura, Tenuta di Castelporziano, Saline di Tarquinia), Regional Nature Reserves (DecimaMalafede, Macchia Tonda, Tor Caldara), Marine Protected Areas (Area Naturale marina protetta secche di Tor Paterno), Protected Areas (Parco Regionale urbano di Monte Orlando, Oasi di Gianola, Oasi blu di Monte Orlando, Oasi blu di Villa di Tiberio, Tempio di Giove Anxur, Oasi di Macchiagrande, Parco Urbano della Pineta di Castel Fusano, Monumento Naturale Palude di Torre Flavia).

According to an ENEA simulation based on projections to the year 2100, the Lazio coast and particularly the Tiber delta and the Agro Pontino area are at high risk of flooding as a result of rising global average temperature. Ongoing research activities focused on the Agro Pontino coast, particularly the physiographic unit from Anzio to Circeo [31], are applying an interdisciplinary methodology to analyze the coastal area from different points of view.

\section{A PROPOSAL FOR INTEGRATING INFRASTRUCTURAL NETWORKS AND THE PROTECTION OF COASTAL AREAS}

The current planning framework of the Lazio region does not have well-defined policies for the coastal strip. In 2013, a Task Force for the Economy of the Sea was established with a view, among other goals, to overcoming the excessive fragmentation of competences and to promoting a structural intervention with a long-term horizon. The results have not been appreciably significant. Similarly, the various sectoral plans have not been upgraded, particularly with regard to the ports where the most recent work is a study conducted in 1998 [32]. As regards infrastructural development, a mobility plan for Lazio region is being developed through a participatory, web-based procedure. The preliminary scenarios with regard to the maritime component envisage only the upgrading of the structures and infrastructures of Lazio's three major ports (Civitavecchia, Fiumicino and Gaeta), and the scenarios for the regional rail network envisage only the adaptation or upgrading of a few sections.

Account taken of the planning framework of Lazio region, the aim of the proposal presented schematically in Fig. 2 is to relaunch a dialog on the coastal strip and identify the elements for the integrated approach described earlier.

The coastal strip is defined in terms of: its different bioregions, the need to safeguard the areas with high rates of biodiversity, and an infrastructural network based on railway links, particularly those linking the shoreline with the longitudinal main lines. The resulting networks will create a series of infrastructural corridors that emanate from the integration of transport planning with territorial planning, and that overcome the decades-long view whereby such corridors should be limited to assuring mobility between two centres. The latter view had unfortunately also been adopted by the European Union in the early 1990s, when the foundations were laid for the development of the Trans-European Transport Network (TEN): large-scale works to connect the major European centres were, in fact, designed without taking into account the mobility needs of intermediate local communities. 


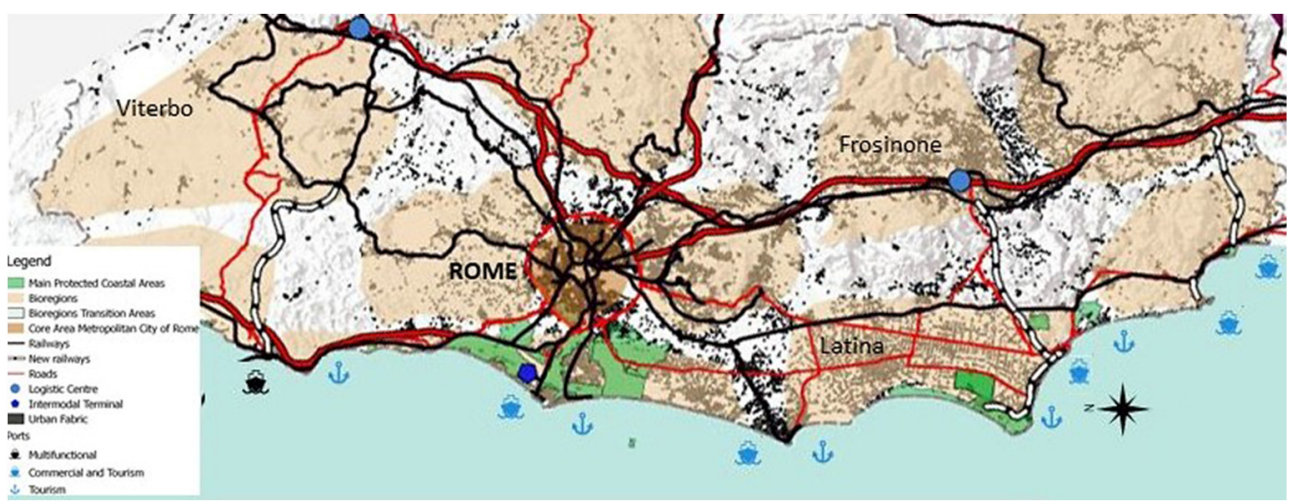

Figure 2: A proposal for integrating infrastructural networks and the protection of coastal areas.

For this reason, this paper defines the word "corridor" as a polysemic term [33], since an infrastructural corridor is simultaneously:

- an infrastructural axis, because it connects different centers located on its path;

- an economic development axis, because it allows the movement of people and goods and can thus favour the location of economic activities;

- an urbanization axis, as the supporting structure for urban development and the redevelopment of adjacent urban fabrics;

- finally, if based on railway links, a corridor may also be an environmental redevelopment axis that helps to overcome the fragmentation caused by road infrastructures while also guaranteeing a modal shift towards less-polluting means of transport. Although railways may also cause fragmentation, the latter effect is only physical and affects the settlements, whereas the fragmentation caused by private automobiles (cars and trucks) is both physical and, through effects such as urban sprawl, social because private cars often carry only one person, the driver.

The proposal envisages the reactivation of three East-West railway links - CivitavecchiaOrte, Terracina-Priverno and Gaeta-Formia - as the structuring principle for reorganizing the rail networks of Lazio region and part of central Italy.

These links follow the region's historical three axes of development (northern, central and southern) mentioned in the Quadro di Assetto Regionale (Regional Development Framework) of 1977 [34]. Today, their reactivation is necessary not only for the movement of passengers and goods but also to support repopulation of the internal areas of Lazio region. The three links would take advantage of parts of disused rail lines that had followed the natural morphologies of the regional territory.

The reactivated links would support the movement both of goods and passengers, with the latter service involving the combined use of trains and tram-trains, i.e. using rolling stock that can travel on different infrastructures and hence reduce the need for passengers to shift between modes. The three corridors are defined as follows:

- the Civitavecchia-Orte link would open a railway corridor for the movement of both people and goods. With a total length $86 \mathrm{~km}$ and crossing 20 municipalities, it would connect the port of Civitavecchia with the freight hub of Orte, one of the largest in the 
region and a pivot for Central Italy's freight traffic. A recent $\mathrm{PhD}$ thesis recommended that this railway link be reactivated in order to enhance the rail transport offer and the repopulation of inner areas [35]. The link would also help implement the BarcelonaPloce transverse corridor whose nodal points in Italy would be the ports of Civitavecchia on the Tyrrhenian Sea and Ortona on the Adriatic Sea [36]. In this corridor the volume of goods transported by rail is expected to rise from the current $14 \%$ to $27 \%$ by 2030 [36];

- the redeveloped Terracina-Priverno link would be extended by adding a section linking Priverno Fossanova to the FL6 rail line (Rome-Cassino) at Ceccano station, then eastwards to the Abruzzo coast. The link may work as follows: from Sabaudia to Ceccano by tram-train; from Ceccano to Roccasecca on the FL6 Rome-Cassino rail line; from Roccasecca to Avezzano on the Roccasecca-Avezzano line; and from Avezzano to Pescara on the Rome-Pescara line. The corridor would thus link the two seas from Sabaudia and the port of Pescara, passing through the port of Terracina, the hinterlands of the Pontina Bioregion, Frosinone Province, the Logistic Center of Frosinone and the Abruzzo region. By doing so, it would strengthen the interregional Lazio-Abruzzo connection as envisaged by the National Platforms included in the new National Logistics Plan 2011-2020 [37];

- the Gaeta-Formia link would connect these two ports of Lazio region by rail to Cassino via the FL7 Roma-Minturno railway line. The construction of a rail link between Cassino and Formia, passing through the Valle dei Santi and providing a second transversal link between the FL6 and FL7 railway lines, has in fact repeatedly been promoted by local authorities who highlight the strong social and economic relationships between Cassino's industrial zones and Formia's commercial port. This corridor has potential for becoming an important axis for the development by strengthening relations between the western and eastern parts of the Mediterranean. The Balkans, in particular, have in recent years become one of the most important economic realities in Europe. According to forecasts released by the Ministry of Infrastructure and Transport regarding Corridor V of the Ten-T Network, the demand for goods transport along this corridor may increase by about 44\%, from 151 to 267 million tons over 20 years [36].

From the standpoint of feasibility, railway construction requires considerable time in terms both of design and execution, and this is hampered by a chronic lack of public funding. A useful instrument for raising part of the financing needed to build the infrastructures is certainly the application of value-capture tools [38]. Part of the higher real estate property values accruing to local populations may be captured through appropriate fiscal instruments to cover part of the costs. For user companies, the enhanced value may be captured by increasing the fees for chamber of commerce registration by $20 \%$ (as done for the Quadrilatero Marche-Umbria road project currently under construction).

\section{CONCLUSIONS}

As seen above and notwithstanding rising anthropic pressures, the regulatory and operational framework for the integrated management of Europe's coastal areas remains uncertain. Indeed, European regulations do not support the implementing of effective planning processes in the areas subject to land-use planning in the various countries. Methodologically, there is broad agreement with regard to the need to improve planning processes, but these need to be based on bottom-up processes that involve civil society; in this sense the bioregion concept provides a useful reference point. In the Italian context, transport planning can make a major contribution to the coordination task entrusted to it by 
law, during the drafting of PRdSPs and the planning of maritime spaces. The effectiveness of its contribution will, however, be conditioned by the extent to which it is both integrated with regional and urban planning and open to a bioregional conception wherein the construction of visions of the future plays an essential role. There is no denying that the Universities can play a major role towards that goal in Lazio region.

\section{REFERENCES}

[1] European Commission, Office for Official Publications of the European Communities, European transport policy for 2010: Time to decide. https:/ec.europa.eu/transport/ sites/transport/files/themes/strategies/doc/2001_white_paper/lb_texte_complet_en. pdf. Accessed on: 16 May 2019.

[2] Communication from the Commission to the European Parliament, the Council, the European Economic and Social Committee and the Committee of the Regions, An Integrated Maritime Policy for the European Union, Brussels, COM(2007) 575 final, 2007. https://eurlex.europa.eu/LexUriServ/LexUriServ.do?uri=COM:2007:0575:FIN: EN:PDF. Accessed on: 16 May 2019.

[3] Communication from the Commission to the Council and the European Parliament on the integrated management of coastal zones COM/95/511 final. https://eurlex.europa.eu/LexUriServ/LexUriServ.do?uri=COM:2000:0547:FIN:EN:PDF. Accessed on: 16 May 2019.

[4] European Commission, Luxembourg: Office for Official Publications of the European Communities, Towards a European Integrated Coastal Zone Management (ICZM) Strategy: General Principles and Policy Options, 1999.

http://ec.europa.eu/environment/iczm/pdf/vol1.pdf. Accessed on: 16 May 2019.

[5] Council Recommendation of the European Parliament and of the Council of 30 May 2002 concerning the implementation of Integrated Coastal Zone Management in Europe (2002/413/EC). https://eur-lex.europa.eu/legal-content/EN/TXT/?uri=CELEX \%3A32002H0413. Accessed on: 16 May 2019.

[6] Directive 2008/56/EC of the European Parliament and of the Council of 17 June 2008 establishing a framework for community action in the field of marine environmental policy (Marine Strategy Framework Directive). https://eur-lex.europa.eu/legalcontent/EN/TXT/?uri=CELEX\%3A32008L0056. Accessed on: 16 May 2019.

[7] Directive 2014/89/EU of the European Parliament and of the Council of 23 July 2014 establishing a framework for maritime spatial planning. https://eur-lex.europa.eu/ legal-content/EN/TXT/?uri=celex\%3A32014L0089. Accessed on: 16 May 2019.

[8] Addis, D., Maricchiolo, C., Ndong, C., Petit, S. \& Skaricic, Z., La Gestione integrata delle zone costiere nelle politiche del Mediterraneo e dell'Unione Europea. Reticula 10, pp. 3-9, 2015.

[9] Simpson, B., Motorways of the sea. Detailed Implementation Plan of the European Coordinator, European Commission - Directorate General for Mobility and Transport. https://ec.europa.eu/transport/sites/transport/files/101_web_final_ii_mos_dip_2018. pdf. Accessed on: 16 May 2019.

[10] AIDEnvironment, National Institute for Coastal and Marine Management/ Rijksinstituut voor Kust en Zee (RIKZ), Coastal Zone Management Centre, the Netherlands, Integrated Marine and Coastal Area Management (IMCAM) approaches for implementing the Convention on Biological Diversity, Montreal, Canada, Secretariat of the Convention on Biological Diversity (CBD Technical Series No. 14), 2004. www.cbd.int/doc/publications/cbd-ts-14.pdf. Accessed on: 16 May 2019. 
[11] Saunders, F., Gilek, M., Day, J., Hassler, B., McCann, J. \& Smythe T., Examining the role of integration in marine spatial planning: Towards an analytical framework to understand challenges in diverse settings. Ocean and Coastal Management, 169, pp. $1-9,2019$.

[12] Janßen, H., Göke, C. \& Luttmann, A., Knowledge integration in marine spatial planning: A practitioners' view on decision support tools with special focus on Marxan. Ocean and Coastal Management, 168, pp. 130-138, 2019.

[13] Scaduto, M.L., Il contratto di costa: un trait d'union tra gestione integrata della costa e pianificazione territoriale? Reticula, 10, pp. 10-16, 2015.

[14] Soja, E.W., Accentuate the regional. International Journal of Urban and Regional Research, 39(2), pp. 372-381, 2015.

[15] Berg, P. \& Darsmann R., Reinhabiting California. Ecologist, 7(10), pp. 399-401, 1977.

[16] Scott Cato, M., The Bioregional Economy. Land, Liberty and the Pursuit of Happiness, Routledge: London and New York, 2013.

[17] Magnaghi, A., Il progetto della bioregione urbana. Regole statutarie e elementi costruttivi. La regola e il progetto Un approccio bioregionalista alla pianificazione territoriale, ed. A. Magnaghi, University Press: Firenze, 2014.

[18] Monceri, F., La classificazione dei porti, Amministrazione In Cammino, 2019. www.amministrazioneincammino.luiss.it/2019/03/15/la-classificazione-dei-porti/. Accessed on: 16 May 2019.

[19] Boscolo, E., La gestione integrata delle zone costiere in Italia: Prospettive e prime esperienze. Rivista Quadrimestrale di diritto dell'ambiente, 1, Giappichielli Editore, 2011.

[20] Cuscito, G., Pechino cerca Roma. Meglio non perdere l'ultimo treno. Limes 2, pp. 8389, 2019.

[21] Vv. Aa., $1^{\circ}$ Forum Nazionale sulla portualità e la logistica. Lo stato di attuazione del Piano Nazionale Strategico, Atti del Convegno, Terminal Crociere-Porto di Bari, 2016.

[22] Cascetta, E., Le autostrade del Mare per connettere l'Italia. Il nuovo Marebonus per una logistica sostenibile, Civitavecchia, 2018

[23] RAM, Una Vision per il Mediterraneo, Report, November 2016.

[24] Commissione presso il Consiglio Superiore dei Lavori Pubblici, Linee guida per la redazione dei Piani Regolatori di Sistema Portuale, Ministero delle Infrastrutture e dei Trasporti 2017. https://va.minambiente.it/it-IT/Comunicazione/DettaglioNotizia/ 1166. Accessed on: 16 May 2019.

[25] Convenzione per la protezione del Mar Mediterraneo dai rischi dell'inquinamento, Convenzione di Barcellona del 1995. www.naturaitalia.it/static/temp/allegati natura_italia/mare/Convenzione_di_Barcellona_IT.pdf. Accessed on: 16 May 2019.

[26] Council Decision of 4 December 2008 on the signing, on behalf of the European Community, of the Protocol on Integrated Coastal Zone Management in the Mediterranean to the Convention for the Protection of the Marine Environment and the Coastal Region of the Mediterranean (2009/89/EC). https://eurlex.europa.eu/legal-content/EN/TXT/?uri=CELEX\%3A32009D0089. Accessed on: 16 May 2019.

[27] Romano, B. et al., Modelli di pressione insediativa e di retrofit nel governo del territorio nelle aree costiere. Reticula, 10, pp. 22-28, 2015.

[28] Legambiente, Abbatti l'abuso. I numeri delle (mancate) demolizioni nei comuni italiani, Report, 2018. 
[29] Ferrovie dello Stato, Atlante delle ferrovie dismesse, 2017. www.fsnews.it/cms-file/ allegati/fsnews2014/2017_11_10_RFI_Atlante_viaggio_ferrovie_dismesse.pdf. Accessed on: 2 Apr. 2019.

[30] I sistemi naturali del Lazio, Regione Lazio. www.parchilazio.it/ricerca_aree. Accessed on: 5 Apr. 2019.

[31] Ministero dell'Ambiente e della Tutela del Territorio e del Mare, Development of a new one-line model to reproduce the long term beaches evolution in presence of coastal defence works and its application to define the sediment management of the coast between Capo d'Anzio and Circeo (Italy) in order to preserve the beaches and the dunes of the Circeo National Park. Department of Civil, Constructional and Environmental Engineering, Sapienza University of Rome (research in progress).

[32] Dipartimento di Idraulica, Trasporti e Strade dell'Università di Roma La Sapienza, Piano di coordinamento dei porti del Lazio, 1998. www.strategiadilisbonalazio.it/ documenti.asp? pagina $=3 \&$ categoria $=1 \&$ sottocategoria $=11$.

[33] Garavaglia, L. \& Pennati, D., I corridoi nello scenario territoriale e urbano italiano. Territorio, 76, pp. 23-27, 2016.

[34] Regione Lazio, Quadro di Riferimento per la programmazione regionale. Studio Preparatorio, Rapporto Regionale, Roma, 1980.

[35] Sperati, S., Infrastrutture ferroviarie secondarie e rigenerazione del territorio. PhD thesis, Sapienza University of Rome, 2017.

[36] Di Pretoro, E. \& Nervagna, A., Il nuovo corridoio mediterraneo, Edizioni Menabò, 2016.

[37] Ministero delle Infrastrutture e di Trasporti, Piano Nazionale della Logistica 20112020, Rome, 2010.

[38] Sumiraschi, C., Catturare il valore. Politiche innovative per finanziare le infrastrutture, Egea: Milano, 2013. 